\title{
Isolation and Characterization of Pb-Solubilizing Bacteria and Their Effects on Pb Uptake by Brassica juncea: Implications for Microbe- Assisted Phytoremediation
}

\author{
Zahra Yahaghi $^{1,2}$, Mehran Shirvani ${ }^{1 *}$, Farshid Nourbakhsh ${ }^{1}$, Teodoro Coba de la Peña ${ }^{2,3}$, José J. Pueyo ${ }^{2}$, and \\ Majid Talebi ${ }^{4}$ \\ ${ }^{1}$ Department of Soil Science, College of Agriculture, Isfahan University of Technology, Isfahan 84156-83111, Iran \\ ${ }^{2}$ Institute of Agricultural Sciences ICA-CSIC, 28006 Madrid, Spain \\ ${ }^{3}$ Centro de Estudios Avanzados en Zonas Áridas (CEAZA), La Serena 1700000, Chile \\ ${ }^{4}$ Department of Agricultural Biotechnology, College of Agriculture, Isfahan University of Technology, Isfahan 84156-83111, Iran
}

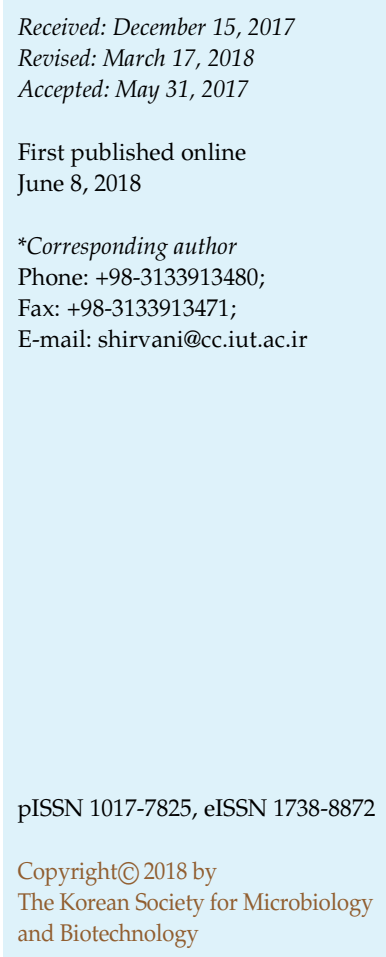

The aim of this study was to isolate and characterize lead $(\mathrm{Pb})$-solubilizing bacteria from heavy metal-contaminated mine soils and to evaluate their inoculation effects on the growth and $\mathrm{Pb}$ absorption of Brassica juncea. The isolates were also evaluated for their plant growthpromoting characteristics as well as heavy metal and salt tolerance. A total of $171 \mathrm{~Pb}$-tolerant isolates were identified, of which only 15 bacterial strains were able to produce clear haloes in solid medium containing $\mathrm{PbO}$ or $\mathrm{PbCO}_{3}$, indicating $\mathrm{Pb}$ solubilization. All of these 15 strains were also able to dissolve the $\mathrm{Pb}$ minerals in a liquid medium, which was accompanied by significant decreases in $\mathrm{pH}$ values of the medium. Based on 16S rRNA gene sequence analysis, the Pb-solubilizing strains belonged to genera Bacillus, Paenibacillus, Brevibacterium, and Staphylococcus. A majority of the Pb-solubilizing strains were able to produce indole acetic acid and siderophores to different extents. Two of the Pb-solubilizing isolates were able to solubilize inorganic phosphate as well. Some of the strains displayed tolerance to different heavy metals and to salt stress and were able to grow in a wide $\mathrm{pH}$ range. Inoculation with two selected $\mathrm{Pb}$-solubilizing and plant growth-promoting strains, (i.e., Brevibacterium frigoritolerans YSP40 and Bacillus paralicheniformis YSP151) and their consortium enhanced the growth and $\mathrm{Pb}$ uptake of $B$. juncea plants grown in a metal-contaminated soil. The bacterial strains isolated in this study are promising candidates to develop novel microbe-assisted phytoremediation strategies for metal-contaminated soils.

Keywords: Metal-solubilizing bacteria, lead, PGPR, contaminated soils, phytoremediation

\section{Introduction}

The growing industrialization and urbanization worldwide have resulted in serious environmental hazards due to the wide array of pollutants, including heavy metals, released into the soil environment. Although trace concentrations of certain heavy metals such as $\mathrm{Fe}, \mathrm{Mn}, \mathrm{Zn}$, and $\mathrm{Cu}$ are essential for living cells, others like $\mathrm{Cd}, \mathrm{Hg}$, and $\mathrm{Pb}$ have no known biological or physiological functions and are even considered to be toxic not only to humans but to plants and microorganisms as well [1]. Among these toxic metals, $\mathrm{Pb}$ has the greatest detrimental impact on human health. Most $\mathrm{Pb}$ concentrations found in the environment are connected to such human activities as metal mining and smelting, lead battery production, leaded petroleum consumption, agricultural use of sewage sludge, and uncontrolled disposal of industrial wastes [2]. Chronic exposure to $\mathrm{Pb}$ increases the risks of high blood pressure, diseases of the nervous system and kidneys, hyperactivity, anemia, and infertility [2]. 
Accumulation of heavy metals in soils enhances their risk of entering the food chain via crop uptake. Humans and animals may also be exposed to these metals through inhalation of contaminated dust and consumption of contaminated waters [3]. To avoid the harmful effects of heavy metals, it is necessary to remediate metal-contaminated sites. Although effective in remediating soils contaminated with heavy metals, particularly those contaminated with high heavy-metal concentrations, traditional cleanup technologies (e.g., thermal treatment, physical separation, electrochemical processes, and acid leaching) are usually expensive and they might also disturb the structure, biogeochemistry, and productivity of the remediated soils [4]. These limitations have led to a growing interest in alternative, less expensive, environmentally friendly, and nondestructive technologies with in situ applicability and high public appeal. Phytoextraction, a common process of phytoremediation, is one such technology that has attracted a lot of attention among researchers. It exploits the potential of green plants to absorb contaminants from the soil and accumulate them in their above-ground tissues, which can then be harvested using conventional agricultural techniques [5].

Metal hyperaccumulators are mostly slow-growing plants with a small biomass, limiting the efficacy of phytoextraction in remediating metal-contaminated sites [6]. Plant growth and biomass production in contaminated soils, and thereby phytoextraction efficiency, can be improved by utilizing plant growth-promoting rhizobacteria (PGPR). PGPR have positive effects on plant performance via such varied mechanisms as phosphorus mobilization, atmospheric nitrogen fixation, iron sequestration by siderophores, and production of phytohormones including auxins like indole acetic acid (IAA) [7-9].

Phytoremediation efficiency is not only limited by the slow growth and low biomass production of hyperaccumulator plants but also by the low bioavailability of heavy metals in many contaminated soils $[9,10]$. A large proportion of heavy metals present in soils is, indeed, either bound to the organic and inorganic soil constituents or precipitated as sparingly soluble minerals. Carbonates, hydroxides, and phosphates are the most important minerals that control the solubility of metals in soils within a $\mathrm{pH}$ range of 5.5-7.5 [11]. Adding chelating agents to soil has been suggested as a means of increasing metal availability to plants [12]. However, application of these expensive compounds has faced increasing criticism on the grounds of their phytoand microorganism-toxicity traits $[13,14]$. One promising alternative proposed to overcome this limitation is the bioaugmentation of contaminated soils with microorganisms that are able to increase metal solubility while also enhancing plant growth and biomass production, and thereby overall metal uptake by plants [8-10]. Jiang et al. [7] reported that an isolated heavy metal-resistant bacterium highly capable of mobilizing $\mathrm{Pb}$ and $\mathrm{Cd}$ carbonates increased not only tomato plant growth but its $\mathrm{Cd}$ and $\mathrm{Pb}$ uptake as well. Sheng et al. [10] showed that soil inoculation with Pseudomonas fluorescens and Microbacterium sp. strains significantly increased the water solubility of lead. Pseudomonas and Bacillus strains have also been reported for their capability to solubilize Zn from sparingly soluble salts $[15,16]$. The release of protons, organic acids, siderophores, and other chelating agents, generation of special metabolites, solubilization of phosphates, and mediation of redox transformations have been suggested as important mechanisms involved in the metal mobilization processes performed by metal-solubilizing bacteria $[16,17]$.

Lots of works have been carried out using PGPR to improve metal phytoextraction, but studies on the application of those PGPR strains capable of metal solubilization to overcome low metal availability in soils, as a bottleneck in phytoremediation efficiency, are rare. Microbial strains with both metal-solubilizing and plant growth-promoting abilities may effectively be used for bioaugmentationphytoremediation of heavy metal-contaminated soils. This study was designed and implemented in pursuit of the following objectives: (i) to isolate and characterize $\mathrm{Pb}$ resistant bacteria from metal contaminated mine soils that are capable of both solubilizing $\mathrm{PbCO}_{3}$ and $\mathrm{PbO}$ as sparingly soluble $\mathrm{Pb}$ compounds, (ii) to examine the plant growthpromoting characteristics of the isolated $\mathrm{Pb}$-solubilizing bacteria, and finally (iii) to evaluate the inoculation effects of the isolated bacteria on the growth and $\mathrm{Pb}$ uptake of Indian mustard (Brassica juncea) grown in a contaminated soil.

\section{Materials and Methods}

\section{Site Description and Soil Sampling}

Two study sites located inside metal mining areas in Isfahan Province, Iran, were selected for soil sampling. Three soil samples were collected from the Bama $\mathrm{Pb} / \mathrm{Zn}$ Mine $\left(51^{\circ} 32^{\prime} \mathrm{E}\right.$ and $32^{\circ} 28^{\prime}$ $\mathrm{N}$ ) and two from the Nakhlak $\mathrm{Pb}$ Mine (53 $50^{\prime} \mathrm{E}$ and $\left.33^{\circ} 34^{\prime} \mathrm{N}\right)$. A portion of the soil samples was kept in sterile zip-lock plastic bags and stored at $4^{\circ} \mathrm{C}$ for bacterial isolation and characterization procedures. Another portion was air-dried, passed through a sieve $(2 \mathrm{~mm})$, and analyzed for important soil properties. The soil $\mathrm{pH}$ and electrical conductivity (EC) were determined in 1:2 
Table 1. Some characteristics of the soils that the $\mathrm{Pb}$-solubilizing bacteria were isolated from.

\begin{tabular}{|c|c|c|c|c|c|c|c|c|c|}
\hline \multirow{2}{*}{ Soil $^{a}$} & \multirow{2}{*}{$\mathrm{pH}^{\mathrm{b}}$} & \multirow{2}{*}{$\begin{array}{c}E C^{b} \\
(\mathrm{dS} / \mathrm{m})\end{array}$} & \multirow{2}{*}{$\begin{array}{l}\text { OC } \\
(\%)\end{array}$} & \multicolumn{4}{|c|}{ DTPA-extractable metals (mg/kg) } & \multicolumn{2}{|c|}{ Total concentration of metals $(\mathrm{mg} / \mathrm{kg})$} \\
\hline & & & & $\mathrm{Cu}$ & $\mathrm{Cd}$ & $\mathrm{Pb}$ & $\mathrm{Zn}$ & $\mathrm{Pb}$ & $\mathrm{Zn}$ \\
\hline $\mathrm{B}_{1}$ & 7.4 & 0.86 & 1.27 & 2.70 & 0.72 & 696 & 225 & 5,489 & 4,200 \\
\hline $\mathrm{B}_{2}$ & 7.8 & 0.47 & 1.10 & 3.80 & 0.99 & 727 & 352 & 7,909 & 4,387 \\
\hline $\mathrm{B}_{3}$ & 7.6 & 1.68 & 2.85 & 1.00 & 0.45 & 174 & 79.80 & 1,343 & 2,325 \\
\hline $\mathrm{N}_{1}$ & 8.5 & 11.70 & 0.22 & 0.92 & 0.32 & 294 & 645 & 5,128 & 3,850 \\
\hline $\mathrm{N}_{2}$ & 7.6 & 17.90 & 0.08 & 0.75 & 0.17 & 688 & 11.10 & 1,866 & 887 \\
\hline
\end{tabular}

${ }^{\mathrm{a}} \mathrm{B}$ and $\mathrm{N}$ represent the Bama and Nakhlak mine soils, respectively.

${ }^{\mathrm{b}} \mathrm{The} \mathrm{pH}$ and EC were measured in a 1:2 soil:water suspension.

EC, electrical conductivity; OC, organic carbon; DTPA, diethylenetriaminepentaacetic acid.

(soil:water) extracts with a glass electrode (Cyberscan 2100) and a conductivity meter (Elmetron CC-501), respectively. The soil organic carbon content was determined using the potassium dichromate-sulfuric acid method [18], total $\mathrm{Pb}$ and $\mathrm{Zn}$ concentrations were measured via digesting soil samples in $6 \mathrm{~N} \mathrm{HNO}_{3}$ [19], and bioavailable $\mathrm{Cd}, \mathrm{Cu}, \mathrm{Pb}$, and $\mathrm{Zn}$ concentrations were estimated using the diethylenetriaminepentaacetic acid (DTPA)- $\mathrm{CaCl}_{2}$ triethanolamine extraction method [20]. Metal concentrations in the extracts were determined with a flame atomic absorption spectrophotometer (FAAS, Z-5300). Some of the properties and metal concentrations of the soils are listed in Table 1.

\section{Isolation and Purification of $\mathrm{Pb}$-Tolerant Bacteria}

The Pb-resistant bacteria were isolated using the Tris-buffered low-phosphate agar (TLP) medium containing sucrose as the carbon source to minimize $\mathrm{Pb}$ complexation to phosphate [21]. The medium was sterilized by autoclaving at $120^{\circ} \mathrm{C}$ for $20 \mathrm{~min}$ and subsequently supplemented with a filter-sterilized $\mathrm{Pb}\left(\mathrm{NO}_{3}\right)_{2}$ solution containing $50 \mathrm{mg}-\mathrm{Pb} / \mathrm{l}$. To prevent soil fungi growth, the media were supplemented with $10 \mathrm{mg} / 1$ of cycloheximide after autoclaving. The soil samples were then serially diluted with a sterile saline solution $(0.85 \% \mathrm{NaCl})$ before $0.1 \mathrm{ml}$ of each dilution was plated on the surface of the TLP medium. The bacterially inoculated plates were incubated at $30^{\circ} \mathrm{C}$ for up to 4 days, and individual colonies of different morphological characteristics, including color, size, form, opacity, and elevation, were selected and streaked on the same medium 3 to 4 times until pure cultures were obtained. The bacterial colonies were then regrown on LuriaBertani (LB) medium and stored for further studies. A total of 171 bacterial isolates showing different morphological appearances on the agar medium were selected for studying the solubilization of $\mathrm{Pb}$ carbonate and oxide minerals.

\section{Isolation of $\mathrm{Pb}$-Solubilizing Bacteria}

In the initial screening test for $\mathrm{Pb}$ tolerance, $110 \mathrm{~Pb}$-resistant strains from the Bama Mine soils and $61 \mathrm{~Pb}$-resistant strains from the Nakhlak Mine soils were isolated using a spread plate procedure and the $\mathrm{pH}$-neutral TLP medium. These strains were subsequently screened to assess their potential to solubilize sparingly soluble $\mathrm{Pb}$ compounds $\left(\mathrm{PbO}\right.$ and $\mathrm{PbCO}_{3}$ ). This ability was revealed by the appearance of clear haloes of solubilization around the colonies in the medium containing sucrose as the carbon source. For this purpose, inocula of the $\mathrm{Pb}$-resistant bacterial isolates were prepared by centrifugation of $2 \mathrm{ml}$ of logarithmic phase grown bacteria at $10,062 \times g$ for $5 \mathrm{~min}$ at $4{ }^{\circ} \mathrm{C}$, washed twice with saline solution $(0.85 \% \mathrm{NaCl})$, and adjusted to about $10^{8} \mathrm{CFU} / \mathrm{ml}$ by suspending in sterile saline solution. Forty microliters of the inocula was spotted onto plates containing a sucrose-minimal salt low-phosphate (SLP) medium (1\% sucrose, $0.1 \%\left(\mathrm{NH}_{4}\right)_{2} \mathrm{SO}_{4}, 0.05 \% \mathrm{~K}_{2} \mathrm{HPO}_{4}, 0.05 \% \mathrm{MgSO}_{4}, 0.01 \% \mathrm{NaCl}$, and $0.05 \%$ yeast extract, $\mathrm{pH}$ 7.2) supplemented with the sparingly soluble $\mathrm{Pb}$ compounds $\mathrm{PbO}$ or $\mathrm{PbCO}_{3}$. The concentration of the metal oxide added to the medium was $1,115 \mathrm{mg} / \mathrm{l}$ and that of the metal carbonate was $500 \mathrm{mg} / \mathrm{l}$. Centrally inoculated plates in triplicate were incubated at $30^{\circ} \mathrm{C}$ for 10 days in the dark. A clear halo against an opaque background was interpreted as the sign of metal solubilization.

\section{Quantification of $\mathrm{Pb}$ Solubilization}

Into 250-ml Erlenmeyer flasks containing $100 \mathrm{ml}$ of the sterile liquid SLP, $500 \mathrm{mg} / \mathrm{l}$ of $\mathrm{Pb}$ as $\mathrm{PbCO}_{3}$ or $1,115 \mathrm{mg} / \mathrm{l}$ of $\mathrm{Pb}$ as $\mathrm{PbO}$ was added, and the medium was then inoculated with $1 \mathrm{ml}$ of the logarithmic phase inoculum at approximately $10^{8} \mathrm{CFU} / \mathrm{ml}$. Media without metal addition and without bacterial inoculation were used as controls. The test flasks were incubated in a rotary shaker in the dark at $180 \mathrm{rpm}$ and $30^{\circ} \mathrm{C}$. After 10 days of incubation, $25 \mathrm{ml}$ of the culture was centrifuged at $8,000 \times g$ for $20 \mathrm{~min}$ and filtered through a $0.22 \mu \mathrm{m}$ Millipore filter. The $\mathrm{Pb}$ concentration in the supernatants was determined by FAAS. The $\mathrm{pH}$ levels of the supernatants were measured with a $\mathrm{pH}$ meter [10].

\section{Plant Growth-Promoting Properties of the Isolates}

IAA production. The $\mathrm{Pb}$-solubilizing bacterial strains were cultured in flasks containing $25 \mathrm{ml}$ of LB medium supplemented with $0.5 \mathrm{mg} / \mathrm{ml}$ of L-tryptophan (filter-sterilized) at $30^{\circ} \mathrm{C}$ on an orbiter shaker at $150 \mathrm{rpm}$. After incubation for 24,48 , and $96 \mathrm{~h}$, $1 \mathrm{ml}$ of the cell-free suspension was mixed vigorously with $2 \mathrm{ml}$ of Salkowski's reagent [22] and allowed to stand at room temperature 
for $20 \mathrm{~min}$. The absorbance of the pink color developed after $25 \mathrm{~min}$ of incubation was read at $530 \mathrm{~nm}$. The IAA concentration in the culture was determined using a calibration curve of pure IAA.

Siderophore production. Siderophore produced by the isolated strains was detected according to the chrome azurol S (CAS) agar method described in Alexander and Zuberer [23]. The bacterial strains were grown twice in the Fe-free SLP medium before the inocula were prepared and adjusted to about $10^{8} \mathrm{CFU} / \mathrm{ml}$ by suspending in a sterile saline solution. Subsequently, $40 \mu \mathrm{l}$ of the inocula was spotted on CAS-agar plates and incubated in the dark for 10 days. Orange-yellow haloes around the colonies on the blue agar were interpreted as siderophore excretion.

Phosphate-solubilizing ability. The phosphate solubilization ability of the strains was determined in Pikovskaya's Agar medium containing $0.5 \%$ tricalcium phosphate [24]. Forty microliters of each bacterial inoculum (about $10^{8} \mathrm{CFU} / \mathrm{ml}$ ) was spotted in Pikovskays's Agar medium and incubated in the dark for 10 days. A clear halo around the colony was interpreted as the bacteria's phosphate solubilization ability.

\section{Genetic Identification}

Characterization of each selected metal-solubilizing bacterium at the genus level was accomplished by partial sequencing of the 16S ribosomal DNA gene. Genomic DNA was extracted with the UltraClean Microbial DNA Isolation Kit (MO BIO Laboratories, Inc., USA) and amplified by the polymerase chain reaction (PCR) using the universal bacterial primers fD1 (5'-AGAGTTTGATCC TGGCTCAG-3') and rP2 (5'-ACGGCTACCTTGTTACGACTT-3') [25]. Each PCR contained $1 \mu \mathrm{l}$ of gDNA and $0.4 \mu \mathrm{M}$ (final concentration) of each primer in a final volume of $50 \mu$ l. The following PCR conditions were used: initial denaturing time of $5 \mathrm{~min}$ at $95^{\circ} \mathrm{C}$, followed by $35 \mathrm{PCR}$ cycles of $95^{\circ} \mathrm{C}$ for $1 \mathrm{~min} ; 55^{\circ} \mathrm{C}$, $1 \mathrm{~min}$; and $72^{\circ} \mathrm{C}, 2 \mathrm{~min}$; and a final extension step at $72^{\circ} \mathrm{C}$ for $10 \mathrm{~min}$. Five microliters of the PCR products was subjected to electrophoretic investigation on a $1 \%$ TAE agarose gel and purified with the Ultra Clean PCR Clean-up Kit (MO BIO Laboratories, Inc.,) according to the manufacturer's instructions. The purified PCR products were sequenced by Secugen (Madrid, Spain). Pairwise alignments were conducted using DNASTAR Lasergene (ver. 7.00) and the 16S rRNA gene sequences thus obtained were compared with those in the GenBank Database using the BLAST program from the NCBI website to determine the percent similarity.

\section{Maximum Tolerance Concentration (MTC) of the Isolates}

The maximum tolerance of the selected isolates against increasing concentrations of heavy metals $(\mathrm{Zn}, \mathrm{Pb}, \mathrm{Cd}$, and $\mathrm{Cu})$ was evaluated on SLP medium at $\mathrm{pH} 6.8$ until the strains were unable to grow colonies on the agar plates. The maximum concentration of heavy metals at which the bacteria still presented growth was designated as the MTC. For this purpose, $10 \mu \mathrm{l}$ of the logarithmic phase bacterial culture at approximately $10^{8} \mathrm{CFU} / \mathrm{ml}$ was drop- inoculated onto Petri dishes in three replicates. A $100 \mathrm{mM}$ stock solution of each metal was prepared using $\mathrm{CdCl}_{2} \cdot 2 \mathrm{H}_{2} \mathrm{O}, \mathrm{CuSO}_{4} \cdot 5 \mathrm{H}_{2} \mathrm{O}$, $\mathrm{ZnSO}_{4} \cdot 7 \mathrm{H}_{2} \mathrm{O}$, and $\mathrm{Pb}\left(\mathrm{NO}_{3}\right)_{2}$ and filtered through a $0.22 \mu \mathrm{m}$ Millipore filter. The plates were incubated at $28^{\circ} \mathrm{C}$ for up to 10 days. This experiment was repeated twice in three replicates [26].

Isolate Tolerance to Acid and Alkaline $\mathrm{pH}$ and Sodium Chloride Experiments were performed to monitor the ranges of $\mathrm{pH}$ and $\mathrm{NaCl}$ concentration at which the isolated bacterial strains maintained their ability to grow on the SLP agar medium [27]. For this purpose, the medium was buffered with $0.1 \mathrm{M}$ sodium acetate/acetic acid at $\mathrm{pH} 4.5,25 \mathrm{mM}$ MES at $\mathrm{pH} 5.5$ and 6.5, $25 \mathrm{mM}$ HEPES at $\mathrm{pH} 7.5,25 \mathrm{mM}$ Tris- $\mathrm{HCl}$ at $\mathrm{pH} 8.5$, and $25 \mathrm{mM}$ sodium carbonate at $\mathrm{pH} 9.5$ and 10.5. Subsequently, $10 \mu \mathrm{l}$ of the exponential phase growing bacteria in the LB medium, at approximately $10^{8} \mathrm{CFU} / \mathrm{ml}$, was drop-inoculated on the medium and incubated at $28^{\circ} \mathrm{C}$ for up to 10 days. In the case of increasing salt concentration, $\mathrm{NaCl}$ from $3 \%$ up to $10 \%$ was added to the medium before autoclaving and the same amount of bacterial inoculum was used each time. These assays were repeated twice in three plates for each treatment.

\section{Influence of Selected Isolates on the Growth and $\mathrm{Pb}$ Uptake of B. juncea}

Preparation of bacterial inocula. Two isolated strains, Brevibacterium frigoritolerans YSP40 and Bacillus paralicheniformis YSP151, both with Pb-solubilizing and plant growth-promoting properties, were selected for inoculation of B. juncea in a greenhouse study. Inocula of the bacterial isolates were prepared by centrifugation of $2 \mathrm{ml}$ of logarithmic phase grown bacteria at $10,062 \times \mathrm{g}$ for $5 \mathrm{~min}$ at $4^{\circ} \mathrm{C}$, washed twice with $0.85 \% \mathrm{NaCl}$ solution, and adjusted to about $10^{8} \mathrm{CFU} / \mathrm{ml}$ by suspending in the same sterile saline solution. A consortium of these two strains was also prepared by mixing equal amounts of the bacterial suspensions.

Soil. Soil collected from a metal-contaminated site around the

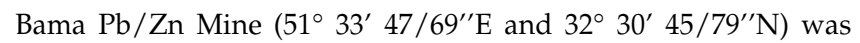
air-dried and sieved to finer than $4 \mathrm{~mm}$. It was characterized as a calcareous silty soil ( $15.6 \%$ sand, $83.5 \%$ silt, $0.9 \%$ clay) with pH 7.4 and an EC equal to $0.72 \mathrm{dS} / \mathrm{m}$. The total $\mathrm{Pb}, \mathrm{Zn}$, and $\mathrm{Cd}$ concentrations of the soil were 446,413 , and $6.2 \mathrm{mg} / \mathrm{kg}$, respectively, as determined by FAAS after soil digestion in $6 \mathrm{~N} \mathrm{HNO}_{3}$ [19].

Pot experiment. Brassica juncea was used for the pot trial because of its fast growth as well as its potential to survive and absorb heavy metals in contaminated soils [5]. Seeds of B. juncea were surface sterilized by soaking in $96 \%$ ethanol for $30 \mathrm{sec}$ and in $5 \%$ sodium hypochlorite solution for $2 \mathrm{~min}$. The seeds were then thoroughly rinsed at least 7 to 8 times with sterile distilled water. Seed inoculations were made by soaking the sterilized seeds in the bacterial suspension for $1 \mathrm{~h}$. Seeds soaked in a sterile saline solution $(0.85 \% \mathrm{NaCl})$ were used as controls. Ten seeds of B. juncea were sown, in triplicates, in a plastic pot containing $2.3 \mathrm{~kg}$ of the metal-contaminated soil. One week after the seedlings had 
emerged, the plants were thinned to six plants per pot and grown under greenhouse conditions at a daytime temperature of $28-34^{\circ} \mathrm{C}$ and a night-time temperature of $17-23^{\circ} \mathrm{C}$. The soil moisture was maintained at $60 \%$ of water holding capacity by adding water on a weight basis throughout the growth period. Four weeks after germination, the bacterial suspensions $(20 \mathrm{ml} /$ pot $)$ were sprayed on the soil surface. The control plants received $20 \mathrm{ml}$ of sterile saline solution $(0.85 \% \mathrm{NaCl})$.

Plant analysis. Plant growth parameters including shoot length as well as shoot and root dry weights were measured. The maximum shoot height was measured before harvesting on day 55 of the growth period. Subsequently, roots were separated and washed extensively with $1 \mathrm{mM} \mathrm{Ca}\left(\mathrm{NO}_{3}\right)_{2} \cdot 4 \mathrm{H}_{2} \mathrm{O}$ and then with distilled water in order to remove surface-adsorbed $\mathrm{Pb}$ ions. Shoot and root dry matters were recorded after oven-drying at $75^{\circ} \mathrm{C}$ for $72 \mathrm{~h}$.

The oven-dried plant samples were digested in a mixture of concentrated $\mathrm{HNO}_{3}-\mathrm{HCl}(70 \%)$ and $\mathrm{H}_{2} \mathrm{O}_{2}(30 \%)$ [28], and the $\mathrm{Pb}$ concentration in the extracts was determined using FAAS. Total $\mathrm{Pb}$ uptake by the plant shoots was calculated as the product of the shoot dry weight and $\mathrm{Pb}$ concentration.

\section{Statistical Analysis}

One-way analysis of variance followed by the least significant difference (LSD) test $(p<0.05)$ using STATISTICA 8 (StatSoft, USA) was applied to compare the potential significant differences between treatments.

\section{Results and Discussion}

\section{General Characteristics of the Metal-Contaminated Soils}

The properties of the soils from which the bacteria were isolated are reported in Table 1. Soil $\mathrm{pH}$ values ranged from 7.4 to 8.5. The soils collected from the Bama Mine had EC values in the range of $0.47-1.68 \mathrm{dS} / \mathrm{m}$ whereas those of the Nakhlak Mine soil ranged from 11.7 to $17.9 \mathrm{dS} / \mathrm{m}$. The total $\mathrm{Pb}$ concentration in the soils ranged from 1,343 to $7,909 \mathrm{mg} / \mathrm{kg}$ and the available (DTPA- $\mathrm{CaCl}_{2}$ extractable) fraction of $\mathrm{Pb}$ in the soils varied from 174 to $727 \mathrm{mg} / \mathrm{kg}$. As judged from these values, all the soils were contaminated with $\mathrm{Pb}$ [29]. The values for total and available metals indicate that the soils were also contaminated with $\mathrm{Zn}$ and Cd [29].

\section{Plant Growth-Promoting Characteristics of the $\mathrm{Pb}$ - Solubilizing Strains}

IAA production. Plant growth enhancement by IAA is mostly due to its stimulating effect on root development, plant cell elongation, and cell division [30-32]. The root system enhancement, in turn, leads to a higher uptake of ions as a result of the larger soil volume made available to the roots.

All the Pb-solubilizing isolates, except YSP66 and YSP40n,

Table 2. Indole acetic acid (IAA) production by the Pb-solubilizing isolates after 24,48 , and $96 \mathrm{~h}$ of incubation. ${ }^{a}$

\begin{tabular}{|c|c|c|c|c|c|c|}
\hline \multirow{3}{*}{ Isolate } & \multicolumn{6}{|c|}{ IAA (mg/l) } \\
\hline & \multicolumn{3}{|c|}{ LB medium } & \multicolumn{3}{|c|}{ LB medium + L-tryptophan (500 mg/l) } \\
\hline & $24 \mathrm{~h}$ & $48 \mathrm{~h}$ & $96 \mathrm{~h}$ & $24 \mathrm{~h}$ & $48 \mathrm{~h}$ & $96 h$ \\
\hline YSP15 & ND & ND & ND & $0.67 \pm 0.09 \mathrm{pq}$ & $0.53 \pm 0.14 \mathrm{q}$ & $0.49 \pm 0.12 \mathrm{q}$ \\
\hline YSP17 & $0.46 \pm 0.18 \mathrm{hj}$ & $0.39 \mathrm{hk}$ & $0.43 \pm 0.17 \mathrm{hk}$ & $4.69 \pm 0.43 \mathrm{hi}$ & $4.2 \pm 0.17 \mathrm{hk}$ & $4.25 \pm 0.29 \mathrm{hk}$ \\
\hline YSP18 & $1.14 \pm 0.11 \mathrm{df}$ & $1.19 \pm 0.11 \mathrm{~d}$ & $1.16 \pm 0.22 \mathrm{de}$ & $1.10 \pm 0.14 \mathrm{nq}$ & $1.61 \pm 0.13 \mathrm{lq}$ & $1.05 \pm 0.14 \mathrm{nq}$ \\
\hline YSP36 & $1.24 \pm 0.33 \mathrm{~d}$ & $0.88 \pm 0.10 \mathrm{~g}$ & $0.88 \pm 0.09 \mathrm{~g}$ & $0.92 \pm 0.30 \mathrm{pq}$ & $1.08 \pm 0.30 \mathrm{nq}$ & $1.03 \pm 0.32 \mathrm{nq}$ \\
\hline YSP40 & $2.58 \pm 0.54 \mathrm{a}$ & $2.85 \pm 0.35 \mathrm{mn}$ & $1.51 \pm 0.15 n$ & $6.64 \pm 0.68 \mathrm{~g}$ & $77.71 \pm 3.33 \mathrm{a}$ & $61.65 \pm 5.49 c$ \\
\hline YSP40n & ND & $0.07 \pm 0.05 \ln$ & ND & ND & $0.12 \pm 0.03 \mathrm{q}$ & ND \\
\hline YSP66 & ND & ND & $0.49 \pm 0.13 \mathrm{hi}$ & ND & ND & $0.97 \pm 0.24 \mathrm{oq}$ \\
\hline YSP69 & ND & $0.19 \pm 0.06 \mathrm{kn}$ & ND & ND & $3.94 \pm 0.11 \mathrm{hk}$ & $1.14 \pm 0.18 \mathrm{nq}$ \\
\hline YSP104 & $0.37 \pm 0.18 \mathrm{hk}$ & ND & ND & $3.41 \pm 0.42 \mathrm{hl}$ & $3.94 \pm 0.16 \mathrm{hk}$ & $3.89 \pm 0.37 \mathrm{hk}$ \\
\hline YSP110 & $0.51 \pm 0.15 \mathrm{hi}$ & $0.47 \pm 0.15 \mathrm{hi}$ & $0.46 \pm 0.10 \mathrm{hj}$ & $1.39 \pm 0.20 \mathrm{nq}$ & $5.23 \pm 0.23 \mathrm{gh}$ & $3.78 \pm 0.12 \mathrm{hk}$ \\
\hline YSP143 & $0.24 \pm 0.06 \mathrm{jm}$ & $0.21 \pm 0.06 \mathrm{kn}$ & $0.31 \pm .03$ il & $2.41 \pm 0.11 \mathrm{kp}$ & $3.24 \pm 0.30 \mathrm{im}$ & $4.04 \pm 0.29 \mathrm{hk}$ \\
\hline YSP149 & $0.45 \pm 0.13 \mathrm{hj}$ & $0.42 \pm 0.08 \mathrm{hk}$ & $0.43 \pm 0.12 \mathrm{hk}$ & $2.85 \pm 0.35 \mathrm{in}$ & $3.25 \pm 0.37 \mathrm{im}$ & $2.80 \pm 0.25$ jo \\
\hline YSP151 & $0.93 \pm 0.20 \mathrm{eg}$ & $0.92 \pm 0.24 \mathrm{fg}$ & $1.62 \pm 0.14 c$ & $4.45 \pm 0.41 \mathrm{hj}$ & $9.21 \pm 0.78 \mathrm{f}$ & $11.41 \pm 0.94 \mathrm{e}$ \\
\hline
\end{tabular}

${ }^{a}$ Data represent the average of three replicates \pm standard deviation. Means in each medium followed by the same letter are not significantly different according to LSD $(p<0.05)$. ND: not detected. 
were found capable of producing IAA in the LB medium supplemented with L-tryptophan (Table 2). The strains YSP40 and YSP24 recorded the highest IAA production rates (Table 2). Moreover, the strains YSP18, YSP24, YSP36, YSP40, and YSP151 produced IAA in the culture medium lacking L-tryptophan (Table 2). Since there are several tryptophan-independent pathways for IAA synthesis [33], it is possible that the latter strains were able to produce IAA without its major precursor, tryptophan. The strains YSP24, YSP40, YSP69, and YSP110 recorded reductions in their IAA content in the medium supplemented with tryptophan after $48-96 \mathrm{~h}$ (Table 2). This might have been due to the degradation of IAA by IAA oxidase secreted by the bacteria or to the storage of IAA in the bacterial cells as previously suggested [34]. The production of IAA has been reported to be common in Bacillus and Paenibacillus species, such as B. subtilis, B. pumilus, and B. cereus $[10,16,24]$.

Siderophore production. Bioaugmentation with siderophore-producing bacteria has been proposed as an efficient strategy to enhance plant growth and metal uptake in phytoremediation practices [35]. In addition, chelation of heavy metals by siderophores has been found to promote bacterial IAA synthesis through reduced oxidative degradation of IAA by free heavy metals [36].

Ten out of the $15 \mathrm{~Pb}$-solubilizing strains were able to produce siderophores (Table 3). Siderophore production levels by the different bacterial strains were compared on the basis of the ratio of colony + haloe diameter to colony diameter. The strains YSP151 and YSP149 exhibited the highest capability for siderophore production (Table 3).

Production of metal-chelating substances, such as organic acids and siderophores, plays a special role in metal detoxification, and thereby in increasing metal tolerance in bacteria. These chelating agents may form complexes with heavy metals that are considered to be less toxic so as to inactivate and minimize the cytological impacts of free metal ions [37]. Abou-Shanab et al. [38] reported that 61.6\% and $42.9 \%$ of the $\mathrm{Pb}$-resistant bacterial strains isolated from the rhizosphere of Diplachne fusca, grown in industrial sites, were siderophore producers and acid producers, respectively.

Phosphate solubilization. Only two Pb-solubilizing strains (YSP24 and YSP95) were able to produce clear haloes on Pikovskaya's medium containing sparingly soluble $\mathrm{Ca}_{3}\left(\mathrm{PO}_{4}\right)_{2}$ as the sole source of phosphate (Table 3). Low $\mathrm{P}$ availability may retard plant growth and metal uptake in phytoremediation practices of contaminated soils [24]. Therefore, selection of bacterial strains capable of increasing P solubility in these soils would be favorable for improving plant growth and, in turn, enhancing metal uptake from these soils [7].

\section{Lead Solubilization Ability of the Isolates}

Only 15 (8.8\%) out of the $171 \mathrm{~Pb}$-resistant isolates showed clear halos in agar plates amended with $\mathrm{PbO}$ or $\mathrm{PbCO}_{3}$. Hence, this ability was not a common feature among the isolated bacteria. Colonies that formed zones of clearance around the colony were selected for further studies.

The isolated strains that were able to form zones of clearance around the colony on the solid medium containing $\mathrm{PbO}$ or $\mathrm{PbCO}_{3}$ were also able to dissolve these minerals in the liquid medium. The results of $\mathrm{Pb}$ solubilization by the isolates and the associated $\mathrm{pH}$ changes in the liquid (SLP) medium are reported in Table 4. Clearly, maximum values of $\mathrm{PbCO}_{3}$ solubilization in the SLP medium were recorded in the presence of strain YSP17 (4.28 mg-Pb/l), followed by YSP104 $(2.64 \mathrm{mg}-\mathrm{Pb} / \mathrm{l})$ and YSP69 (2.16 mg-Pb/l), which were 26.7, 16.5, and 13.5 times higher than that of the control, respectively (Table 4). In the PbO-containing SLP medium, the maximum value of $\mathrm{Pb}$ concentration was recorded with inoculation of the strains YSP69, YSP40n, and YSP110 (8.99, 8.73, $8.42 \mathrm{mg}-\mathrm{Pb} / \mathrm{l}$, respectively), which were more than 30 times higher than that of the control. The bacterial isolates might have increased dissolution of the $\mathrm{Pb}$-bearing minerals through such mechanisms as ligand-promoted dissolution induced by the bacterial metabolites and proton-promoted dissolution triggered by a $\mathrm{pH}$ decrease $[39,40]$. Nevertheless, the magnitude of metal solubilization by a bacterial isolate varies depending

Table 3. Siderophore production and P solubilization abilities of the Pb-solubilizing isolates.

\begin{tabular}{|c|c|c|c|c|c|c|c|c|c|c|c|c|c|c|c|}
\hline & \multicolumn{15}{|c|}{ Isolate } \\
\hline & YSP15 & YSP17 & YSP18 & YSP24 & YSP36 & YSP40 & YSP40n & YSP66 & YSP69 & YSP95 & YSP104 & YSP110 & YSP143 & YSP149 & YSP151 \\
\hline $\begin{array}{l}\text { Siderophore } \\
\text { production }^{\mathrm{a}}\end{array}$ & 0 & 1.12 & 0 & 0 & 1.92 & 1.55 & 0 & 0.8 & 1.67 & 1.00 & 0.33 & 1.41 & 0 & 2.25 & 3.83 \\
\hline P solubilization ${ }^{\mathrm{b}}$ & - & - & - & + & - & - & - & - & - & + & - & - & - & - & - \\
\hline
\end{tabular}

${ }^{a}$ Data represent the colony + haloes diameter/colony diameter ratio on CAS-agar medium.

${ }^{\mathrm{b}}+$, Clear halo produced on Pikovskaya's medium; -, No clear halo on Pikovskaya's medium. 
Table 4. Total soluble $\mathrm{Pb}$ and final $\mathrm{pH}$ measured in $\mathrm{PbCO}_{3}$ - and $\mathrm{PbO}$-containing SLP broth medium after inoculation with $\mathrm{Pb}$ solubilizing bacterial isolates.

\begin{tabular}{|c|c|c|c|c|c|}
\hline \multirow{2}{*}{ Bacterial isolate } & \multicolumn{2}{|c|}{$\mathrm{Pb}$ liberated ${ }^{\mathrm{a}}(\mathrm{mg} / \mathrm{l})$} & \multicolumn{3}{|c|}{ Final $\mathrm{pH}$ of the medium } \\
\hline & $\mathrm{PbCO}_{3}$ & $\mathrm{PbO}$ & $\mathrm{PbCO}_{3}$ & $\mathrm{PbO}$ & Control $^{\mathrm{b}}$ \\
\hline YSP15 & $1.48 \pm 0.26 \mathrm{e}$ & $0.91 \pm 0.08 \mathrm{~g}$ & $5.95 \pm 0.08 b$ & $6.98 \pm 0.07 b$ & $6.76 \pm 0.18 \mathrm{ab}$ \\
\hline YSP17 & $4.28 \pm 0.15 \mathrm{a}$ & $2.13 \pm 0.44$ ef & $4.04 \pm 0.12 \mathrm{~g}$ & $6.60 \pm 0.26 c$ & $4.54 \pm 0.06 \mathrm{~h}$ \\
\hline YSP18 & $0.36 \pm 0.02 \mathrm{i}$ & $1.81 \pm 0.15$ ef & $5.71 \pm 0.12 b$ & $5.60 \pm 0.17 \mathrm{e}$ & $6.85 \pm 0.09 a$ \\
\hline YSP24 & $1.98 \pm 0.18 \mathrm{~cd}$ & $1.74 \pm 0.10 \mathrm{f}$ & $4.27 \pm 0.50 \mathrm{efg}$ & $4.01 \pm 0.16 \mathrm{~h}$ & $4.81 \pm 0.07 \mathrm{~g}$ \\
\hline YSP40 & $1.61 \pm 0.20 \mathrm{de}$ & $2.35 \pm 0.25 \mathrm{de}$ & $4.94 \pm 0.14 \mathrm{c}$ & $6.26 \pm 0.13 \mathrm{~d}$ & $6.53 \pm 0.08 b$ \\
\hline YSP40n & $1.02 \pm 0.02 \mathrm{fg}$ & $8.73 \pm 0.38 a$ & $4.38 \pm 0.11$ def & $4.27 \pm 0.05 \mathrm{~h}$ & $5.45 \pm 0.06 \mathrm{de}$ \\
\hline YSP66 & $1.45 \pm 0.39 \mathrm{e}$ & $0.84 \pm 0.08 \mathrm{gh}$ & $4.07 \pm 0.08 \mathrm{fg}$ & $6.01 \pm 0.13 \mathrm{~d}$ & $5.26 \pm 0.14$ ef \\
\hline YSP69 & $2.16 \pm 0.02 c$ & $8.99 \pm 0.26 \mathrm{a}$ & $4.43 \pm 0.19 \mathrm{de}$ & $4.27 \pm 0.14 \mathrm{~h}$ & $4.49 \pm 0.13 h$ \\
\hline YSP95 & $0.21 \pm 0.11 \mathrm{i}$ & $2.18 \pm 0.72$ ef & $5.93 \pm 0.18 b$ & $5.12 \pm 0.16 \mathrm{~g}$ & $5.1 \pm 0.16 \mathrm{f}$ \\
\hline YSP110 & $0.81 \pm 0.02 \mathrm{gh}$ & $8.42 \pm 0.76 a$ & $4.15 \pm 0.13 \mathrm{efg}$ & $4.20 \pm 0.19 \mathrm{~h}$ & $5.26 \pm 0.09$ ef \\
\hline YSP143 & $0.47 \pm 0.03 \mathrm{hi}$ & $0.67 \pm 0.08 \mathrm{gh}$ & $4.46 \pm 0.17 \mathrm{de}$ & $5.65 \pm 0.30 \mathrm{e}$ & $5.58 \pm 0.05 \mathrm{~cd}$ \\
\hline YSP149 & $1.98 \pm 0.06 \mathrm{~cd}$ & $0.81 \pm 0.21 \mathrm{gh}$ & $4.60 \pm 0.15 \mathrm{~d}$ & $6.59 \pm 0.05 c$ & $4.19 \pm 0.18 \mathrm{i}$ \\
\hline YSP151 & $1.36 \pm 0.42 \mathrm{ef}$ & $5.82 \pm 0.52 c$ & $4.43 \pm 0.11 \mathrm{de}$ & $5.29 \pm 0.17 \mathrm{fg}$ & $5.18 \pm 0.20 \mathrm{f}$ \\
\hline Control $^{\mathrm{c}}$ & $0.16 \pm 0.10 \mathrm{i}$ & $0.27 \pm 0.05 \mathrm{~h}$ & $7.56 \pm 0.06 \mathrm{a}$ & $7.36 \pm 0.18 \mathrm{a}$ & $6.90 \pm 0.10 a$ \\
\hline
\end{tabular}

${ }^{a} \mathrm{SLP}$ medium supplemented with 1,115 mg/1 $\mathrm{PbO}$ or $500 \mathrm{mg} / 1 \mathrm{PbCO}_{3}$ and inoculated with different bacterial strains.

${ }^{\mathrm{b}} \mathrm{SLP}$ medium inoculated with different bacterial strains without Pb salts.

'SLP medium supplemented with 1,115 mg/1 $\mathrm{PbO}$ or $500 \mathrm{mg} / 1 \mathrm{PbCO}_{3}$ without bacterial inoculation.

Means in each column followed by the same letter are not significantly different according to LSD $(p<0.05)$.

on the mineral composition and solubilization mechanism(s) exploited by the isolate. Li et al. [39], for example, showed that $B$. cepacia possessed different mobilization abilities on metal compounds with the descending order of $\mathrm{ZnCO}_{3}>$ $\mathrm{CdCO}_{3}>\mathrm{ZnO}>>\mathrm{PbCO}_{3}$.

Bacterial-induced metal solubilization of minerals has frequently been attributed to ligand-promoted dissolution of minerals caused by bacterial metabolites such as siderophores, carboxylic organic acid anions, and biosurfactants [41]. Abou-Shanab et al. [42], for instance, demonstrated that growth products of B. subtilis and B. pumilus increased $\mathrm{Zn}, \mathrm{Cu}$, and $\mathrm{Pb}$ solubilization in soils. They suggested that siderophore production by these bacterial strains had a major effect on metal solubilization. Siderophores can form stable soluble complexes with heavy metals such as $\mathrm{Pb}$ or Fe $[43,44]$ and increase the solubility of metal-bearing minerals. Pseudomonas aeruginosa was reportedly able to produce siderophores when inoculated in $\mathrm{Cr}-$ and $\mathrm{Pb}$ polluted soils, leading not only to increased concentrations of bioavailable $\mathrm{Cr}$ and $\mathrm{Pb}$ in the rhizosphere but to significantly enhanced $\mathrm{Cr}$ and $\mathrm{Pb}$ accumulation in maize shoots as well [43]. In addition, bacterially mediated scavenging of metals from insoluble mineral sources has been attributed to the production and secretion of such organic acids as gluconic, oxalic, tartaric, formic, and lactic acids $[7,9,15,39]$. It has been suggested that the presence of sparingly soluble metal compounds in the growth medium might induce the production of carboxylic acid anions, leading to the enhanced dissolution of metal ions from the solid phase [39].

The $\mathrm{pH}$ of the SLP medium inoculated with the $\mathrm{Pb}$ solubilizing bacterial strains decreased both in the presence and absence of $\mathrm{Pb}$ minerals (Table 4), suggesting the role of the bacterial strains in producing $\mathrm{H}^{+}$probably through organic acid secretion $[7,15]$. Bacteria may also acidify their environment by the export of protons for the maintenance of charge balance [42]. The greatest drops in $\mathrm{pH}$ level (about 3 units) in the control SLP medium were induced by the strains YSP149 and YSP69. In the PbOcontaining medium, the largest decrease in $\mathrm{pH}$ was measured in the presence of YSP24, whereas YSP17 and YSP66 gave rise to the largest $\mathrm{pH}$ decreases in the $\mathrm{PbCO}_{3}$ containing medium. These results are in agreement with those reported by Ji et al. [34], who found that solubilization 
of $\mathrm{Cd}, \mathrm{Pb}$, and $\mathrm{Zn}$ carbonates by Serratia marcescens M6 and Rhodotorula mucilaginosa K1 was accompanied by significant $\mathrm{pH}$ decreases in the medium. Long et al. [16] also showed that inoculation of several endophytic bacterial strains induced both a $\mathrm{pH}$ drop and $\mathrm{Zn}$ solubilization in culture media containing $\mathrm{ZnCO}_{3}$ and $\mathrm{Zn}_{3}\left(\mathrm{PO}_{4}\right)_{2}$. However, they found that $\mathrm{Zn}_{3}\left(\mathrm{PO}_{4}\right)_{2}$ solubilization was 100 times greater, whereas the $\mathrm{pH}$ did not change, in a medium inoculated with Pseudomonas fluorescens (strain II2R3).

\section{Molecular Identification of the Pb-Solubilizing Bacteria}

Table 5 presents the isolated $\mathrm{Pb}$-solubilizing strains identified on the basis of $16 \mathrm{~S}$ rRNA gene sequences. The size of the PCR products generated with the selected bacterial isolates ranged from approximately 784 to $1,351 \mathrm{bp}$.
Based on a sequence identity of $97 \%$ or greater, the closest matches of the isolates were determined using BLAST. The results show a preponderance of the Bacillus species (Table 5). This is also confirmed by other studies that revealed the presence or dominance of Bacillus species in mine soils or those contaminated with heavy metals [45-47].

\section{Tolerance to Heavy Metals, $\mathrm{NaCl}$, and $\mathrm{pH}$}

Among the $15 \mathrm{~Pb}$-solubilizing isolates, 10 strains were selected for further experiments according to their best performance in $\mathrm{Pb}$ solubilization and PGPR traits. Mine soils most often contain more than one metal, and tolerance to several heavy metals is a desirable trait for bacteria with potential use in phytoremediation. All the isolates tested were found to exhibit multiple tolerance to high

Table 5. Identification of isolated $\mathrm{Pb}$-solubilizing bacteria.

\begin{tabular}{|c|c|c|c|c|c|c|}
\hline \multirow[b]{2}{*}{ Isolates } & \multirow[b]{2}{*}{ Source soil } & \multirow{2}{*}{$\begin{array}{l}\text { Length of } 16 S \\
\text { rRNA gene } \\
\text { sequenced (bp) }\end{array}$} & \multirow{2}{*}{$\begin{array}{c}\text { GenBank } \\
\text { Accession } \\
\text { No. }\end{array}$} & \multicolumn{3}{|c|}{ Most closely related organism } \\
\hline & & & & Species (strain) & Accession No. & $\begin{array}{l}\% \text { Gene } \\
\text { identity }\end{array}$ \\
\hline YSP24 & Nakhlak mine & 1,346 & KY887778 & Paenibacillus illinoisensis (strain NBRC 15959) & NR_113828.1 & 99 \\
\hline YSP36 & Nakhlak mine & 1,065 & KY887779 & Bacillus simplex (strain RD36) & KJ_534463.1 & 97 \\
\hline YSP40n & Nakhlak mine & 1,351 & KY887781 & Staphylococcus pasteuri (strain ATCC51129) & NR_024669.1 & 100 \\
\hline YSP69 & Bama mine & 1,313 & KY887782 & Bacillus cereus (strain CCM2010) & NR_115714.1 & 99 \\
\hline YSP104 & Bama mine & 1,158 & KY887783 & Bacillus altitudinis(strain 41KF2b) & NR_042337.1 & 100 \\
\hline YSP110 & Bama mine & 1,156 & KY887784 & Bacillus filamentosus (strain SGD-14) & NR_134701.1 & 99 \\
\hline YSP149 & Bama mine & 1,219 & KY887785 & Bacillus licheniformis(strain ATCC14580) & NR_074923.1 & 99 \\
\hline
\end{tabular}

Table 6. Maximum tolerance concentration of the $\mathrm{Pb}$-solubilizing isolates against heavy metals and $\mathrm{NaCl}$ and ability of the isolates to grow in different $\mathrm{pH}$ ranges.

\begin{tabular}{|c|c|c|c|c|c|c|}
\hline Isolate & $\begin{array}{c}\mathrm{Pb} \\
(\mathrm{mg} / \mathrm{l})\end{array}$ & $\begin{array}{c}\mathrm{Zn} \\
(\mathrm{mg} / \mathrm{l})\end{array}$ & $\begin{array}{c}\mathrm{Cu} \\
(\mathrm{mg} / \mathrm{l})\end{array}$ & $\begin{array}{c}\mathrm{Cd} \\
(\mathrm{mg} / \mathrm{l})\end{array}$ & $\begin{array}{c}\mathrm{NaCl} \\
(\%)\end{array}$ & $\mathrm{pH}$ range \\
\hline YSP17 & 207.20 & 65.38 & - & 22.48 & 9 & $5.5-10.5$ \\
\hline YSP36 & 207.20 & 13.07 & - & - & 3 & $5.5-10.5$ \\
\hline YSP40 & 207.20 & 65.38 & 6.35 & - & 3 & $5.5-10.5$ \\
\hline YSP69 & 414.40 & 130.76 & 12.71 & 224.82 & 8 & $5.5-10.5$ \\
\hline YSP104 & 414.40 & 196.14 & 6.35 & 112.41 & 8 & $5.5-10.5$ \\
\hline YSP110 & 414.40 & 130.76 & 6.35 & 112.41 & 10 & $5.5-10.5$ \\
\hline YSP149 & 207.20 & 65.38 & 6.35 & 112.41 & 10 & $5.5-10.5$ \\
\hline YSP151 & 207.20 & 68.38 & 6.35 & 11.24 & 9 & 5.5-10.5 \\
\hline
\end{tabular}

- , No bacterial growth observed. 
concentrations of metals, especially to $\mathrm{Pb}$ and $\mathrm{Zn}$ (Table 6). The highest MTC values were detected for $\mathrm{Pb}(\geq 207.2 \mathrm{mg} / \mathrm{l})$, indicating that the isolates were highly resistant to $\mathrm{Pb}$. YSP69, YSP104, and YSP110 were the most tolerant to Pb, but also to $\mathrm{Zn}, \mathrm{Cu}$, and $\mathrm{Cd}$. Sheng et al. [48] also reported that a Bacillus sp. strain, isolated from metal-contaminated soils, was not only resistant to $\mathrm{Pb}(200 \mathrm{mg} / \mathrm{l})$ and $\mathrm{Cd}$ (20 mg/l), but also to $\mathrm{Cu}(50 \mathrm{mg} / \mathrm{l}), \mathrm{Ni}(20 \mathrm{mg} / \mathrm{l})$, and $\mathrm{Zn}$ (100 mg/l).

The $\mathrm{Pb}$-solubilizing bacterial strains tested displayed a notable tolerance to salt stress while they were also able to grow well in a $\mathrm{pH}$ range of 5.5-10.5, except for YSP40n that did not grow at $\mathrm{pH}$ levels higher than 9.5 (Table 6). Bioaugmentation by salt-tolerant bacteria can both promote plant growth and help extract heavy metals in phytoremediation practices of salt-affected, metalcontaminated soils of arid regions [49]. The $\mathrm{pH}$ and salt tolerance of the $\mathrm{Pb}$-solubilizing strains tested points to the feasibility of using them in contaminated soils also affected by moderately acid or alkaline $\mathrm{pH}$ levels and/or elevated salinity.

\section{Effects of $\mathbf{P b}$-Solubilizing Strains on the Growth and $\mathbf{P b}$ Uptake of B. juncea}

Effects of Brevibacterium frigoritolerans YSP40 and Bacillus paralicheniformis YSP151 strains and their consortium (YSP40+YSP151) on the growth parameters of B. juncea are presented in Table 7. Inoculation with YSP151 led to significant $(p<0.05)$ increases in plant shoot length and dry weight by 2.9 and 2.4 times, respectively, compared with those of the non-inoculated plant. The corresponding plant shoot growth parameters were also increased by 2.8 and 2.2 times, respectively, as a result of plant inoculation with YSP40 (Table 7). Effects of the bacterial consortium were significant on the shoot length (2.6-fold) but not on the shoot dry weight of the plant (Table 7). No significant differences were observed in root dry weight between Indian mustard plants grown in inoculated and non- inoculated soils (Table 7). Growth retardation of plants due to the presence of excess heavy metals in soil is a common feature observed in many plant species [10, 50, 51]. However, plant growth-promoting bacteria can facilitate plant growth in harsh environments like metal-contaminated soils by their activities, such as IAA, siderophore, and 1-aminocyclopropane-1-carboxylate deaminase (ACCD) production, and phosphate solubilization [32, 37, 52]. Burd et al. [53] reported that the plant growth-promoting bacterium Kluyvera ascorbata SUD165 contributed to the resistance of Brassica napus against nickel toxicity. Sheng et al. [8] also reported that inoculation of soil with Bacillus edaphicus NBT having IAA, siderophore, and ACCD production capabilities resulted in increases of $22 \%$ and $30 \%$, respectively, in root and shoot dry matter values of $B$. juncea grown in the presence of $800 \mathrm{mg}-\mathrm{Pb} / \mathrm{kg}$. Kumar et al. [50] inoculated B. juncea with Enterobacter sp. to observe enhanced plant growth parameters.

Table 7 reports $\mathrm{Pb}$ accumulation levels in the roots and shoots of B. juncea plants. Clearly, inoculation with YSP151 and YSP40+YSP150 significantly increased $\mathrm{Pb}$ concentrations in the shoots when compared with those of the noninoculated plants. The root $\mathrm{Pb}$ concentration was not, however, significantly affected by the bacterial inoculation treatments (Table 7). The increased $\mathrm{Pb}$ absorption by the plants might have been due to improved $\mathrm{Pb}$ solubilization and $\mathrm{pH}$ reduction by bacterial activities in the soil.

The total $\mathrm{Pb}$ uptake by plant shoots was 3.2 and 4.6 times higher than that of the control when the plants were inoculated with Brevibacterium frigoritolerans YSP40 and Bacillus paralicheniformis YSP151 strains, respectively (Table 7). The increased total $\mathrm{Pb}$ uptake by plant shoots might be ascribed to enhancements in both plant shoot biomass and $\mathrm{Pb}$ accumulation in the shoot as a result of bacterial inoculation. Sheng et al. [8] reported that the shoot $\mathrm{Pb}$ content of B. juncea inoculated with Bacillus edaphicus NBT increased by $46 \%$, compared with the non-inoculated plants, in a soil polluted with $800 \mathrm{mg}-\mathrm{Pb} / \mathrm{kg}$. Inoculation

Table 7. Inoculation effects of Brevibacterium frigoritolerans YSP40 and Bacillus paralicheniformis YSP151 strains and their consortium on the growth and $\mathrm{Pb}$ absorption of Brassica juncea.

\begin{tabular}{lcccccc}
\hline $\begin{array}{c}\text { Inoculated } \\
\text { strain }\end{array}$ & $\begin{array}{c}\text { Shoot } \\
\text { length } \\
(\mathrm{cm})\end{array}$ & $\begin{array}{c}\text { Shoot } \\
\text { dry weight } \\
(\mathrm{g} / \text { pot })\end{array}$ & $\begin{array}{c}\text { Root } \\
\text { dry weight } \\
(\mathrm{g} / \mathrm{pot})\end{array}$ & $\begin{array}{c}\text { Shoot Pb } \\
\text { concentration } \\
(\mathrm{mg} / \mathrm{kg})\end{array}$ & $\begin{array}{c}\text { Root Pb } \\
\text { concentration } \\
(\mathrm{mg} / \mathrm{kg})\end{array}$ & $\begin{array}{c}\text { Pb uptake } \\
\text { by shoot } \\
(\mu \mathrm{g} / \mathrm{pot})\end{array}$ \\
\hline Non (control) & $12.30 \pm 2.08 \mathrm{~b}$ & $1.84 \pm 0.79 \mathrm{c}$ & $0.16 \pm 0.19 \mathrm{a}$ & $38.23 \pm 2.9 \mathrm{c}$ & $96.93 \pm 6 \mathrm{~b}$ & $69.01 \pm 24.73 \mathrm{c}$ \\
YSP40 & $34.83 \pm 7.09 \mathrm{a}$ & $3.99 \pm 0.59 \mathrm{ab}$ & $0.39 \pm 0.05 \mathrm{a}$ & $55.31 \pm 10.1 \mathrm{~b}$ & $79.55 \pm 6.5 \mathrm{~b}$ & $224.1 \pm 67.36 \mathrm{~b}$ \\
YSP151 & $35.68 \pm 2.17 \mathrm{a}$ & $4.38 \pm 0.55 \mathrm{a}$ & $0.82 \pm 0.82 \mathrm{a}$ & $73.6 \pm 13.6 \mathrm{a}$ & $141.7 \pm 35.2 \mathrm{a}$ & $319.7 \pm 48.62 \mathrm{a}$ \\
YSP40+YSP151 & $32.30 \pm 1.88 \mathrm{a}$ & $2.89 \pm 0.36 \mathrm{bc}$ & $0.38 \pm 0.06 \mathrm{a}$ & $67.16 \pm 5.3 \mathrm{ab}$ & $80.94 \pm 5.7 \mathrm{~b}$ & $193.1 \pm 14.82 \mathrm{~b}$ \\
\hline
\end{tabular}

Values are the mean \pm standard deviation. Means in each column followed by the same letter are not significantly different according to LSD ( $p<0.05)$. 
with the YSP40+YSP110 consortium also significantly increased the $\mathrm{Pb}$ content of Indian mustard compared with that of the un-inoculated control; however, its beneficial effect was generally lower compared with that of YSP151 single inoculation (Table 7). Abou-Shanab et al. [42] also showed that a mixture of B. subtilis, B. pumilus, Pseudomonas pseudoalcaligenes, and Brevibacterium halotolerans increased the $\mathrm{Cu}$ concentration in shoots of Zea mays growing on $\mathrm{Cu}$ rich soils, but this increase was less pronounced than that obtained after inoculation of Br. halotolerans alone.

The present study highlighted the role of bacterial strains isolated from mine soils in increasing soil metal availability and uptake by plants, for remediating metal-contaminated sites more efficiently. Since the potential of a plant for use as a phytoremediator in a metal-contaminated soil relies on the total metal quantity taken up by the harvestable part of the plant biomass, inoculation of the metal-solubilizing and plant growth-promoting strains, such as Brevibacterium frigoritolerans YSP40 and Bacillus paralicheniformis YSP151, could be recommended as a good way of increasing the phytoremediation rate and efficiency of $\mathrm{Pb}$-polluted soils.

\section{Acknowledgments}

This work was supported by grants from Isfahan University of Technology and MINECO (AGL2013-40758-R).

\section{Conflict of Interest}

The authors have no financial conflicts of interest to declare.

\section{References}

1. Nagajyoti PC, Lee KD, Sreekanth TVM. 2010. Heavy metals, occurrence and toxicity for plants: a review. Environ. Chem. Lett. 8: 199-216.

2. Thornton I, Rautiu R, Brush S. 2001. Lead: The Facts. Ian Allan Printing Ltd., London.

3. Triantafyllidou S, Edwards M. 2009. Lead (Pb) in U.S. drinking water: school case studies, detection challenges and public health considerations. In: Your Drinking Water: Challenges and Solutions for the 21st Century. Drinking Water Symposium, April 20th \& 21st, 2009, Yale University.

4. Dermont G, Bergeron M, Mercier G, Richer-Laflèche M. 2008. Soil washing for metal removal: a review of physical/ chemical technologies and field applications. J. Hazard. Mater. 152: 1-31.

5. Jabeen R, Ahmad A, Iqbal M. 2009. Phytoremediation of heavy metals: physiological and molecular mechanisms. Bot.
Rev. 75: 339-364.

6. Shao HB, Chu LY, Ni FT, Guo DG, Li H, Li WX. 2010. Perspective on phytoremediation for improving heavy metal-contaminated soils, pp. 227-244. In Ashraf M, Ozturk M, Ahmad MSA (eds.), Plant Adaptation and Phytoremediation. Dordrecht, Springer.

7. Jiang CY, Sheng XF, Qian M, Wang QY. 2008. Isolation and characterization of a heavy metal-resistant Burkholderia sp. from heavy metal-contaminated paddy field soil and its potential in promoting plant growth and heavy metal accumulation in metal-polluted soil. Chemosphere 72: 157-164.

8. Sheng XF, Jiang CY, He LY. 2008. Characterization of plant growth-promoting Bacillus edaphicus NBT and its effect on lead uptake by Indian mustard in a lead-amended soil. Can. J. Microbiol. 54: 417-422.

9. Sheng XF, Xia JJ. 2006. Improvement of rape (Brassica napus) plant growth and cadmium uptake by cadmium-resistant bacteria. Chemosphere 64: 1036-1042.

10. Sheng X-F, Xia JJ, Jiang CY, He LY, Qian M. 2008. Characterization of heavy metal-resistant endophytic bacteria from rape (Brassica napus) roots and their potential in promoting the growth and lead accumulation of rape. Environ. Pollut. 156: 1164-1170.

11. Lindsay WL. 1979. Chemical Equilibrium in Soils. Wiley Interscience Publishers, New York.

12. Zhao S, Jia L, Duo L. 2013. The use of biodegradable chelators for enhanced phytoextraction of heavy metals by Festuca arundinacea from municipal solid waste compost and associated heavy metal leaching. Bioresour. Technol. 129: 249-255.

13. Evangelou MWH, Bauer U, Ebel M, Schaeffer A. 2007. The influence of EDDS and EDTA on the uptake of heavy metals of $\mathrm{Cd}$ and $\mathrm{Cu}$ from soil with tobacco, Nicotiana tabacum. Chemosphere 68: 345-353.

14. Usman ARA, Almaroai YA, Ahmad M, Vithanage M, Ok YS. 2013. Toxicity of synthetic chelators and metal availability in poultry manure amended $\mathrm{Cd}, \mathrm{Pb}$ and As contaminated agricultural soil. J. Hazard. Mater. 262: 1022-1030.

15. Fasim F, Ahmed N, Parsons R, Gadd GM. 2002. Solubilization of zinc salts by a bacterium isolated from the air environment of a tannery. FEMS Microbiol. Lett. 213: 1-6.

16. Long XX, Chen XM, Chen YG, Wong JW-C, Wei ZB, Wu QT. 2011. Isolation and characterization endophytic bacteria from hyperaccumulator Sedum alfredii Hance and their potential to promote phytoextraction of zinc polluted soil. World J. Microbiol. Biotechnol. 27: 1197-1207.

17. Braud A, Jézéquel K, Vieille E, Tritter A, Lebeau T. 2006. Changes in extractability of $\mathrm{Cr}$ and $\mathrm{Pb}$ in a poly contaminated soil after bioaugmentation with microbial producers of biosurfactants, organic acids and siderophores. Water Air Soil Pollut. 6: 261-279.

18. Nelson DW, Sommers LE. 1996. Total carbon, organic carbon, and organic matter, pp. 961-1010. In Sparks DL (ed.), Method of Soil Analysis, Part 3, Chemical Methods. Soil 
Science Society of America, Inc., American Society of Agronomy, Madison, WI.

19. Zheljazkov VD, Nielsen NE. 1996. Effect of heavy metals on peppermint and cornmint. Plant Soil 178: 59-66.

20. Lindsay WL, Norvell WA. 1978. Development of a DTPA soil test for zinc, iron, manganese, and copper. Soil Sci. Soc. Am. J. 42: 421-428.

21. Mergeau MD, Nies HG, Schlegel J, Gerits P, Charles van Gijsegem F. 1985. Alcaligenes eutrophus CH34 is a facultative chemolitotroph with plasmid-bound resistance to heavy metals. J. Bacteriol. 162: 328-334.

22. Gordon SA, Weber RP. 1951. Colorimetric estimation of indole acetic acid. Plant Physiol. 26: 192-195.

23. Alexander DB, Zuberer DA. 1991. Use of chrome Azurol-S reagents to evaluate siderophore production by rhizosphere bacteria. Biol. Fertil. Soils 12: 39-45.

24. Zaidi S, Usmani S, Singh BR, Musarrat J. 2006. Significance of Bacillus subtilis strain SJ-101 as a bio inoculant for concurrent plant growth promotion and nickel accumulation in Brassica juncea. Chemosphere 64: 991-997.

25. Weisburg WG, Barns SM, Pelletier DA, Lane DJ. 1991. 16 S ribosomal DNA amplification for phylogenetic study. J. Bacteriol. 173: 697-703.

26. Affan QA, Shoeb E, Badar U, Akhtar J. 2009. Isolation and characterization of bacterial isolates having heavy metal tolerance. J. Basic Appl. Sci. 5: 55-60.

27. Nonnoi $\mathrm{F}$, Chinnaswamy A, de la Torre VSG, de la Peña TC, Lucas MM, Pueyo JJ. 2012. Metal tolerance of rhizobial strains isolated from nodules of herbaceous legumes (Medicago spp. and Trifolium spp.) growing in mercurycontaminated soils. Appl. Soil Ecol. 61: 49-59.

28. Jones JB Jr, Case VW. 1990. Sampling, handling, and analyzing plant tissue samples, pp. 389-447. In Westerman RL (ed.), Soil Testing and Plant Analysis. Soil Science Society of America, Inc., Madison, WI.

29. NYS. 2006. New York State Brownfield Cleanup Program Development of Soil Cleanup Objectives Technical Support Document. New York State Department of Environmental Conservation and New York State Department of Health, Albany, NY. Available from http://www.dec.ny.gov/ chemical/34189.html.

30. Davies PJ. 2010. The Plant Hormones: Their Nature, Occurrence and Functions, 3rd Ed. Kluwer Academic Publishers, New York.

31. Malhotra M, Srivastava S. 2009. Stress-responsive indole-3acetic acid biosynthesis by Azospirillum brasilense SM and its ability to modulate plant growth. Eur. J. Soil Biol. 45: 73-80.

32. Patten CL, Glick BR. 2002. The role of bacterial indole acetic acid in the development of the host plant root system. Appl. Environ. Microbiol. 68: 3795-3801.

33. Ribeiro CM, Cardoso EJBN. 2012. Isolation, selection and characterization of root-associated growth promoting bacteria in Brazil Pine (Araucaria angustifolia). Microbiol. Res. 167: 69-78. 34. Ji LY, Zhang WW, Yu D, Cao YR, Xu H. 2012. Effect of heavy metal-solubilizing microorganisms on zinc and cadmium extractions from heavy metal contaminated soil with Tricholoma lobynsis. World J. Microbiol. Biotechnol. 28: 293-301.

35. Rajkumar M, Ae N, Narasimha M, Prasad V, Freitas H. 2009. Potential of siderophore-producing bacteria for improving heavy metal phytoextraction. Trends Biotechnol. 28: 142-149.

36. Dimkpa CO, Merten D, Svatoš A, Büchel G, Kothe E. 2009. Metal-induced oxidative stress impacting plant growth in contaminated soil is alleviated by microbial siderophores. Soil Biol. Biochem. 41: 154-162.

37. Gao Y, Miao C, Mao L, Zhou P, Jin Z, Shi W. 2010. Improvement of phytoextraction and antioxidative defense in Solanum nigrum L. under cadmium stress by application of cadmium-resistant strain and citric acid. J. Hazard. Mater. 181: 771-777.

38. Abou-Shanab RA, Ghozlan H, Ghanem K, Moawad H. 2005. Behavior of bacterial populations isolated from rhizosphere of Diplachne fusca dominant in industrial sites. World J. Microbiol. Biotechnol. 21: 1095-1101.

39. Li WC, Ye ZH, Wong MH. 2010. Metal mobilization and production of short-chain organic acids by rhizosphere bacteria associated with a $\mathrm{Cd} / \mathrm{Zn}$ hyperaccumulating plant, Sedum alfredii. Plant Soil 326: 453-467.

40. Ma Y, Prasad MNV, Rajkumar M, Freitas H. 2011. Plant growth promoting rhizobacteria and endophytes accelerate phytoremediation of metalliferous soils. Biotechnol. Adv. 29: 248-258.

41. Sessitsch A, Kuffner M, Kidd P, Vangronsveld J, Wenzel WW, Fallmann K, et al. 2013. The role of plant-associated bacteria in the mobilization and phytoextraction of trace elements in contaminated soils. Soil Biol. Biochem. 60: 182-194.

42. Abou-Shanab RA, Ghanem K, Ghanem N, Al-Kolaibe A. 2008. The role of bacteria on heavy-metal extraction and uptake by plants growing on multi-metal-contaminated soils. World J. Microbiol. Biotechnol. 24: 253-262.

43. Braud A, Jézéquel K, Bazot S, Lebeau T. 2009. Enhanced phytoextraction of an agricultural $\mathrm{Cr}$ - and $\mathrm{Pb}$-contaminated soil by bioaugmentation with siderophore-producing bacteria. Chemosphere 74: 280-286.

44. Dimkpa CO, Merten D, Svatoš A, Büchel G, Kothe E. 2009. Siderophores mediate reduced and increased uptake of cadmium by Streptomyces tendae F4 and sunflower (Helianthus annuus), respectively. J. Appl. Microbiol. 107: 1687-1696.

45. Dhal B, Thatoi H, Das N, Pandey BD. 2010. Reduction of hexavalent chromium by Bacillus sp. isolated from chromite mine soils and characterization of reduced product. J. Chem. Technol. Biotechnol. 85: 1471-1479.

46. Govarthanan M, Lee KJ, Cho M, Kim JS, Kamala-Kannan S, 
Oh BT. 2013. Significance of autochthonous Bacillus sp. KK1 on biomineralization of lead in mine tailings. Chemosphere 90: 2267-2272.

47. Seralathan K, Kui JL. 2008. Metal tolerance and antibiotic resistance of Bacillus species isolated from Sunchon Bay, South Korea. Biotechnology 7: 149-152.

48. Sheng XF, He LY, Wang QY, Ye HS, Jiang CY. 2008. Effects of inoculation of biosurfactant-producing Bacillus sp. J119 on plant growth and cadmium uptake in a cadmium-amended soil. J. Hazard. Mater. 155: 17-22.

49. Teixeira C, Almeida CMR, Nunes da Silva M, Bordalo AA, Mucha AP. 2014. Development of autochthonous microbial consortia for enhanced phytoremediation of salt-marsh sediments contaminated with cadmium. Sci. Total Environ. 493: 757-765.
50. Kumar KV, Singh N, Behl NH, Srivastava S. 2008. Influence of plant growth promoting bacteria and its mutant on heavy metal toxicity in Brassica juncea grown in fly ash amended soil. Chemosphere 72: 678-683.

51. Tangahu BV, Abdullah SRS, Basri H, Idris M, Anuar N, Mukhlisin MA. 2011. Review on heavy metals (As, Pb, and $\mathrm{Hg}$ ) uptake by plants through phytoremediation. Int. J. Chem. Eng. 2011: 939161.

52. Kumari B, Singh SN. 2011. Phytoremediation of metals from fly ash through bacterial augmentation. Ecotoxicology 20: 166-176.

53. Burd GI, Dixon DG, Glick BR. 1998. A plant growth-promoting bacterium that decreases nickel toxicity in seedlings. Appl. Environ. Microbiol. 64: 3663-3668. 